\title{
Seasonal prevalence of the larvae of the nasal fly (Cephalopina titillator) in camels in Jordan
}

\author{
Falah Al-Ani ${ }^{1}$ Zuhair Amr ${ }^{2 *}$
}

\section{Keywords}

Camelus dromedarius, Cephalopina titillator, myiasis, seasonality, morbidity, Jordan

Submitted: 5 June 2016

Accepted: 18 October 2016

Published: 30 January 2017

\begin{abstract}
Summary
The seasonal prevalence of the larvae of Cephalopina titillator infesting camels was studied at Ramtha slaughterhouse in Jordan. Of the 97 camels examined, 45 were infested (46\%). Larvae were found every month of the year with the highest infestation rate in January and the lowest between May and July. The number of recovered larvae ranged from 12 to 113, with an average of 43. Most larvae were attached to the mucosa of the nasopharynx, whereas a few were found in the nasal cavity. Most first-instar larvae were found in the labyrinth of the ethmoid bone, whereas second- and third-instar larvae were mainly seen in the pharyngeal cavity. Degenerated larvae were also observed in the frontal and nasal sinuses.
\end{abstract}

- How to cite this article : Al-Ani F., Amr Z. 2016. Seasonal prevalence of the larvae of the nasal fly (Cephalopina titillator) in camels in Jordan. Rev. Elev. Med. Vet. Pays Trop., 69 (3): 125-127

\section{INTRODUCTION}

Infestation of camels (Camelus dromedarius ) by the tropical botfly (Cephalopina titillator) as a causative agent of nasal myiasis has been reported from several countries including Iraq (Al-Ani et al., 1991), Libya (Abd El-Rahman, 2010), Saudi Arabia (Banaja and Ghandour, 1994), Sudan (Musa et al., 1989) and Iran (Oryan et al., 2008). Parasitic infections in camels in Jordan have been studied on several occasions and include reports on the presence of $C$. titillator (Sharrif, et al. 1998; Al-Ani et al. 1998; Al-Rawashdeh et al., 2000).

C. titillator is an obligate parasite infecting all breeds and both sexes of camels (Higgins, 1985). One- to three-year-old animals are most severely affected (Abu-Hab and Al-Affass, 1977; Hussein et al., 1982). The infestation seasonality of the larval stages of this fly in camels has been studied in Egypt (Ashmawy et al., 1985), Iraq (AbuHab and Al-Affass, 1977), North Sinai (Morsy et al., 1998), Saudi Arabia (Fatani and Hilali, 1994; Alahmed, 2002) and countries of Asia and Africa.

The adult fly lives freely and collects around the head of the camels. It lays its larvae around the nostrils. The larvae then migrate via

\footnotetext{
1. Biology Unit, College of Applied Sciences, A'Sharqiyah University, Ibra, Sultanate of Oman.

2. Department of Biology, Jordan University of Science and Technology, Jordan.

* Corresponding author

Email: amrz@just.edu.jo
}

nasal airways to the nasopharyngeal area where they stay several months and develop from larvae-1, to larvae-2, to larvae-3, increasing in size to $25-35 \mathrm{~mm}$ in length. At this stage the larvae make their way back up the nasal airways causing considerable irritation in the camel. During this process the larvae are sometimes expelled after a great deal of snorting, which results in their inevitable expulsion out onto the ground. In the present paper we studied the prevalence of $C$. titillator infestation in camels in Jordan. Clinical and pathological changes were also reported.

\section{MATERIALS AND METHODS}

Over a one-year period, 97 camels slaughtered at Al-Ramtha slaughterhouse were examined for camel nasal myiasis. Samples were collected once a week during which three to eight camels were slaughtered. Shortly before slaughtering, a general physical examination was conducted. After slaughtering, the head was dissected and gross examination was performed on the nasal cavity, frontal sinuses, turbinate bones and nasopharyngeal area. The presence or absence of the different stages of larvae was checked and all larvae were removed and counted.

Larvae of $C$. titillator were identified according to Zumpt (1965). The gross damage to the local tissue was described and photographed. Selective tissue samples were collected, preserved in buffered $10 \%$ formalin solution and processed by standard histopathological techniques and stained with hematoxylin and eosin.

Monthly annual rainfall in Ramtha was obtained from the Department of Metrology for the past 10 years. 


\section{RESULTS}

\section{Prevalence}

Out of the 97 camels examined, 45 were infested with larval stages of $C$. titillator with an overall prevalence of $46.39 \%$. Table I shows the monthly infestation of camels according to the larval stages of $C$. titillator. The number of recovered larvae ranged from 12 to 113 per month, with an average of 43.25 (standard deviation \pm 23.59 ).

\section{Seasonality of Cephalopina titillator infestation}

Table I shows the seasonality of infestation of camels with larval stages of $C$. titillator. The larvae infested the camels every month of the year. However, their prevalence was highest in January, and lowest in June and July (Figure 1). The number of infested camels was high during the cold months of the year (November to February), declined in summer then increased again in late summer (August). Adult flies, as L1, are active during October and November. After this period, no adult is active and only few L1 were seen in the infected calmels.

\section{Table I}

Prevalence of camel nasal botfly (Cephalopina titillator) in camels between October 1999 and September 2000 in Jordan

\begin{tabular}{lllllr} 
& $\begin{array}{c}\text { Num. of camels } \\
\text { examined }\end{array}$ & $\begin{array}{l}\text { Num. of camels } \\
\text { infested (\%) }\end{array}$ & \multicolumn{3}{c}{$\begin{array}{c}\text { Num. of } \\
\text { larvae }\end{array}$} \\
\cline { 3 - 6 } & & & L1 & L2 & L3 \\
\hline Oct. 1999 & 11 & $4(36.36)$ & 8 & 7 & 7 \\
Nov. 1999 & 12 & $4(33.3)$ & 3 & 8 & 6 \\
Dec. 1999 & 10 & $6(60)$ & 0 & 5 & 19 \\
Jan. 2000 & 8 & $7(87.5)$ & 0 & 4 & 26 \\
Feb. 2000 & 8 & $6(75)$ & 0 & 8 & 44 \\
Mar. 2000 & 4 & $3(75)$ & 0 & 0 & 95 \\
Apr. 2000 & 8 & $4(50)$ & 0 & 0 & 86 \\
May 2000 & 17 & $3(17.64)$ & 0 & 2 & 111 \\
June 2000 & 5 & $1(20)$ & 0 & 3 & 30 \\
July 2000 & 4 & $1(25)$ & 0 & 0 & 12 \\
Aug. 2000 & 7 & $4(57.14)$ & 0 & 0 & 19 \\
Sept. 2000 & 3 & $2(66.67)$ & 0 & 0 & 14 \\
\hline Total & 97 & $45(46.39)$ & 11 & 37 & 469
\end{tabular}

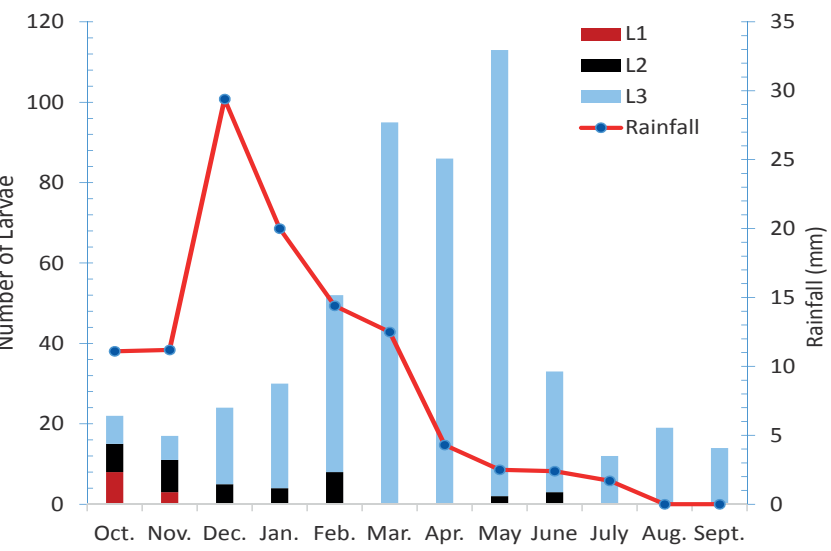

Figure 1: Monthly infestation among camels slaughtered at AlRamtha slaughterhouse in Jordan and annual monthly rainfall (October 1999 - September 2000).
Later on, there is a hypobiotic period extending from February to September. There is a hypobiotic phase of larvae when an evolutive stage is predominant. This is the case for $\mathrm{L} 3$ of $C$. titillator.

\section{Clinical and pathological changes}

Most larvae were found attached to the mucosa of the nasopharynx, whereas a few were found in the nasal cavity. Degenerated larvae were also observed in the frontal and nasal sinuses. Most of first instar larvae were found in the labyrinth of the ethmoid bone, whereas second and third instars larvae were mostly observed in the nasopharyngeal area (Figures 2 and 3). The nasal cavities and sinuses were congested and, where some of the larvae were present, red nodules in nasopharyngeal mucosae indicated the sites of larval attachment. Histological changes included desquamation of the epithelial cells with infiltration of different types of leukocytes such as neutrophils, eosinophils and lymphocytes in the inflamed areas.

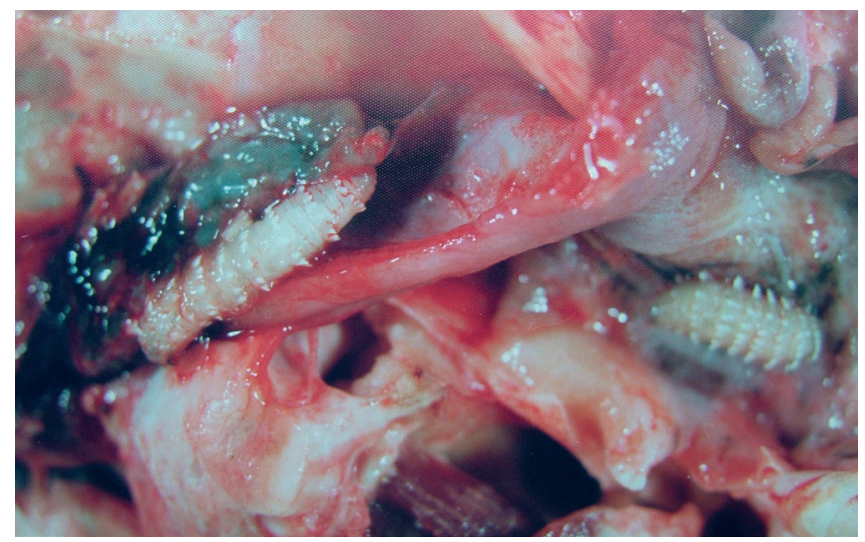

Figure 2: Gross lesions caused by nasal fly larvae in the nasopharyngeal mucosa of a camel.
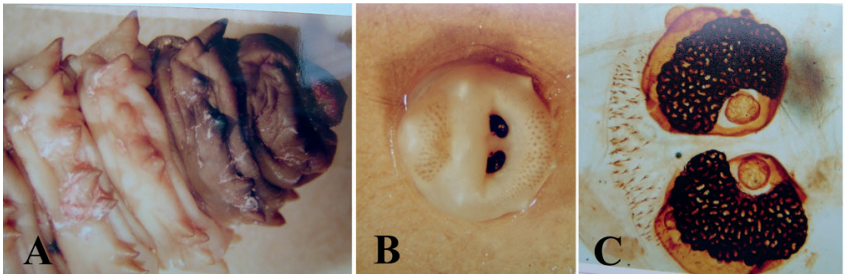

Figure 3: Morphology of Cephalopina titillator recovered from camels. A: Third instar larva. B: Stigmal plate. C: Close up of the stigmal plate.

\section{DISCUSSION}

Parasitic infestations are of concern to camels in different parts of the world (El-Bihari, 1980; Al-Ani et al., 1998). The larvae bury themselves in the ground to pupate and develop into adult flies in about 25 days (Barker, 1964). In Iran, Oryan et al. (2008) found that infestation by the nasal fly was significantly more severe in the colder months $(69.8 \%)$ than in the warmer ones (36.2\%), and in males $(65.0 \%)$ than in females $(45.60 \%)$. Also they found that the prevalence rate was lower in camels under two years of age (39.8\%) than in camels aged 2 to 6 years (61.5\%) and over 6 years (62.8\%). Morsy et al. (1998) reported monthly and seasonal prevalence of $C$. titillator larvae in slaughtered camels in Egypt, an infestation rate of 25\%, and they observed that the highest prevalence periods were in October and in autumn. All three larval instars were found in the infested 
camels. However, third instars were the predominant stage (60.59\%), followed by second instars (30.58\%), then by first instars (8.83\%).

Hussein et al. (1983) reported camel nasal flies in 1672 (67.6\%) of 2473 indigenous Saudi camels examined at Riyadh abattoir between April 1981 and March 1982. The average monthly prevalence of the infestation ranged from $29 \%$ to $89 \%$, and the highest rate was from August to March. In Iraq Al-Ani et al. (1991) found that $73.8 \%$ of the camels slaughtered in September, October November and December were infested. Also Abul-Hab and Al-Affass (1977) found that camels aged 1-3 years were the most severely affected.

Severe larva infestation causes nasal myiasis in the camel and may restrict airflow resulting in difficulty in breathing (Hussein et al., 1982). Some authors even suggest it may cause camel mortality. Al-Ani et al. (1991) reported that a few camels develop nervous signs as a secondary complication of nasal myiasis. Only a few camels develop the neurological disorders characterized by depression, listlessness, walking in circles and stiffness. The camels may finally die from meningitis caused by Diplococcus pneumoniae that has been isolated in pure culture from cerebrospinal fluid (Al-Ani et al., 1991).

\section{Acknowledgments}

The authors thank staff members at Jordan Badia Research and Development Center for their cooperation, their help to access to the camel herders to visit different locations, and collect samples from camels in Jordan Badia.

\section{REFERENCES}

Abd El-Rahman S., 2010. Prevalence and pathology of nasal myiasis in camels slaughtered in El-Zawia Province, Western Libya: with a reference to thyroid alteration and renal lipidosis. Global Vet., 4 (2): 190-197

Abul-Hab J., Al-Affass N.N., 1977. Seasonal occurrence of the domestic camel botfly Cephalopina titillator, Diptera, Oestridae in camels in Iraq. Bull. Biol. Res. Cent., 8: 97-104

Alahmed A.M., 2002. Seasonal prevalence of Cephalopina titillator larvae in camels in Riyadh region, Saudi Arabia. Arab Gulf J. Sci. Res., 20 (3): 161-164

Al-Ani F.K., Khamas W.A., Zenad K.H., 1991. Camel nasal myiasis: clinical, epidemiological and pathological studies in Iraq. Indian J. Anim. Sci., 61: 576-578

Al-Ani F.K., Sharrif L.A., Al-Rawashdeh O.F., Al Qudah K.M., Al-Hammi Y., 1998. Camel diseases in Jordan. In: Proc. Third Annual Meeting for Animal Production Under Arid Conditions. United Arab Emirates University, Abu Dhabi, 2: 77-92

\section{Résumé}

Al-Ani F., Amr Z. Prévalence saisonnière des larves de la mouche des naseaux (Cephalopina titillator) chez le chameau en Jordanie

La prévalence saisonnière des larves de Cephalopina titillator infestant les chameaux a été étudiée à l'abattoir de Ramtha en Jordanie. Parmi les 97 chameaux examinés, 45 étaient infestés (46\%). Des larves ont été retrouvées tous les mois de l'année avec les taux d'infestation les plus élevés en janvier et les plus bas entre mai et juillet. Le nombre de larves observées a varié de 12 à 113 avec une moyenne de 43. La plupart des larves étaient fixées à la muqueuse du nasopharynx et quelques-unes étaient dans la cavité nasale. La plupart des larves de premier stade étaient dans le labyrinthe de l'os ethmoïde, tandis que les larves de deuxième et de troisième stades se trouvaient dans la cavité pharyngienne. Des larves dégénérées étaient aussi présentes dans les sinus naseaux et frontaux.

Mots-clés: Camelus dromedarius, Cephalopina titillator, myiasis, saisonnalité, morbidité, Jordanie
Al-Rawashdeh O.F., Al-Ani F.K., Sharrif L.A., Al-Qudah K.M., AlHami Y., Frank N., 2000. A survey of camel (Camelus dromedarius) diseases in Jordan. J. Zoo Wildl. Med., 31 (3): 335-338, doi: 10.1638/1042-7260(2000)031[0335:ASOCCD]2.0.CO;2

Ashmawy K.I., Fahmy M.M., Hilali M., 1985. Incidence and seasonal variations of the larvae of Cephalopina titillator infesting camels (Camelus dromedarius) in Egypt. In: Proc. 12th Symp. Scandinavian Society of Parasitology, Tromsy, Norway, 17-19 June, 1985. Abo Akademi, Finland, p. 43-44

Banaja A.A., Ghandour A.M., 1994. A review of parasites of camels (Camelus dromedarius) in Saudi Arabia. J. King Abdulaziz Univ. Sci. Ser., 6: 75-86

Barker H.M., 1964. Camels and the outback. Isaac Pitman \& Sons, Melbourne, Australia. 139 p.

El-Bihari S., 1980. Helminths of the camel: a review. Br. Vet. J., 141: 315-326, doi: 10.1016/0007-1935(85)90070-3

Fatani A., Hilali M., 1994. Prevalence and monthly variations of the second and third instars of Cephalopina titillator (Diptera: Oestridae) infesting camels (Camelus dromedarius) in the Eastern Province of Saudi Arabia. Vet. Parasit., 53 (1/2): 145-151, doi: 10.1016/0304-4017(94)90026-4

Higgins A.J., 1985. The camel in health and disease. 4. Common ectoparasites of the camel and their control. Br. Vet. J., 141: 197-216, doi: 10.1016/00071935(85)90153-8

Hussein M.F., El-Amin F.M., El-Taib N.T., Basmaeil S.M., 1982. The pathology of nasopharyngeal myiasis in Saudi Arabian camels (Camelus dromedarius). Vet. Parasit., 9: 253-160, doi:10.1016/0304-4017(82)90060-7

Hussein M.F., Hassan H.A.R., Bilal H.K., Basmae'il S.M., Younis T.M., Al-Motlaq A.A.R., Al-Sheikh M.A., 1983. Cephalopina titillator (Clark 1797) infection in Saudi Arabian camels. Zoonoses Public Health, 30: 553-558, doi: 10.1111/ j.1439-0450.1983.tb01882.x

Morsy T.A., Aziz A.S., Mazyad S.A., Al Sharif K.O., 1998. Myiasis caused by Cephalopina titillator (Clark) in slaughtered camels in Al Arish abattoir, North Sinai governorate, Egypt. J. Egypt. Soc. Parasitol., 28 (1): 67-73

Musa M.T., Harrison M., Ibrahim A.M., Taha T.O., 1989. Observations on Sudanese camel nasal myiasis caused by the larvae of Cephalopina titillator. Rev. Elev. Med. Vet. Pays Trop., 42 (1): 27-31

Oryan A., Valinezhad A., Moraveji M., 2008. Prevalence and pathology of camel nasal myiasis in eastern areas of Iran. Trop Biomed., 25 (1): 30-36

Sharrif L., Al-Rawashdeh O.M., Al-Qudah K.M., Al-Ani F.K., 1998. Prevalence of gastrointestinal helminthes, hydatid cysts and nasal myiasis in camels in Jordan. In: Proc. Third Annual Meeting for Animal Production Under Arid Conditions. United Arab Emirates University, Abu Dhabi, 2: 108-114

Zumpt F., 1965. Myiasis in man and animals in the Old World. A textbook for physicians, veterinarians and zoologists. Butterworth's, London, UK

\section{Resumen}

Al-Ani F., Amr Z. Prevalencia estacional de la larva de la mosca nasa (Cephalopina titillator) en camellos en Jordania

Se estudió la prevalencia estacional de la infestación de larva de Cephalopina titillator en camellos en el matadero de Ramtha en Jordania. De los 97 camellos examinados, 45 estaban infestados (46\%). Se encontraron larvas cada mes del año, con la mayor tasa de infestación en enero y la más baja de mayo a julio. El número de larvas recuperadas varió de 12 a 113, con un promedio de 43. La mayoría de las larvas estaban pegadas a la mucosa de la nasofaringe, mientras que algunas se encontraron en la cavidad nasal. La mayoría de las larvas de primer estadio se encontraron en el laberinto del hueso etmoides, mientras que las larvas de segundo y tercer estadio fueron principalmente observadas en la cavidad faríngea. Larvas degeneradas fueron también observadas en los senos frontal y nasal.

Palabras clave: Camelus dromedarius, Cephalopina titillator, miasis, estacionalidad, morbosidad, Jordan 
